\title{
Antioxidant Capacity and Acute Testicular Toxicity of Leucaena leucocephala Aqueous Shoot Tips Plus Young Leaves Extracts
}

\author{
Capacidad Antioxidante y Toxicidad Testicular Aguda de Brotes Acuosos \\ con Extracto de Hojas Nuevas de Leucaena leucocephala
}

Jaturon Burawat"; Nongnut Uabandit*; Bungorn Sripanidkulchaii*; Somsak Nualkaew ${ }^{* * * *}$ \& Sitthichai Iamsaard ${ }^{*, * *}$

BURAWAT, J.; UABANDIT, N.; SRIPANIDKULCHAI, B.; NUALKAEW, S. \& IAMSAARD, S. Antioxidant capacity and acute testicular toxicity of Leucaena leucocephala aqueous shoot tips plus young leaves extracts. Int. J. Morphol., 34(2):514-521, 2016.

SUMMARY: This study aimed to determine the antioxidant capacity of the Leucaena leucocephala aqueous shoot tips plus young leaves (LL-spl) extracts among three different fractions (LL-spl 10, 20, and $40 \mathrm{~min}$ ) and to examine its acute toxicity on male reproductive parameters. The amount of the total phenolics in LL-spl extract was determined using a Folin-Ciocalteu reagent method and its antioxidant capacity was analyzed using 1, 1-diphenyl 1-2-picrylhydrazyl radical scavenging and ferric reducing antioxidant powder methods. The LL-spl extract fraction with highest antioxidant capacity was used in animal treating. Male rats were divided into three groups $(n=5)$; control and groups treated with LL-spl 400 and $600 \mathrm{mg} / \mathrm{Kg}$ body weight for consecutive 40 days. The results showed that the LL-spl $40 \mathrm{~min}$ fraction possessed the highest antioxidant capacity. In addition, the LL-spl 400 and 600 groups showed no differences in weights of body, testis and epididymis, serum testosterone levels, and expression of testicular steroidogenic acute regulatory (StAR) protein. Significantly, LL-spl extract reduced the weight of seminal vesicle, sperm concentration, and seminiferous diameters compared with control. Moreover, LL-spl extract had adverse effect on testicular histology in inducing of seminiferous atrophy and degeneration including dilated blood vessels in interstitial tissue. It was concluded that although LL-spl extract possessing antioxidant capacity, in short term consumptions, it could be toxic to some male reproductive organs especially damaging testicular tissues.

KEY WORDS: Leucaena leucocephala; Shoot tips plus young leaves; Antioxidant capacity; Acute testicular toxicity.

\section{INTRODUCTION}

The Leucaena leucocephala (Lam.) de Wit (also called "Krathin ban" in Thai) is promoted as a miracle plant that has been used as multiple properties in tropical and warm temperate region of many countries including Thailand (Gutteridge \& Shelton, 1998). In general literature, $L$. leucocephala $(\mathrm{LL})$ has nutritive values and various potential uses. LL shoot tips have been traditionally used to relieve diarrhea (Chanwitheesuk et al., 2005). The seeds of this plant have broad spectrum medicinal properties including antiproliferative, cancer chemo-protective, anthelmintic, antidiabetic, control stomachache, and antibacterial activities (Syamsudin et al., 2010; Gamal-Eldeen et al., 2007; Ademola et al., 2005; Chang et al., 1999; Villaseñor et al., 1997). LL seeds are also used as antifertility substances in folk medicine. In addition, both young and mature leaves of LL are used as human food, animal feed, fish and poultry diets because they have high nutritive contents like crude proteins, fats, carbohydrates, and important chemical constituents (Orwa et al., 2009; Alabi \& Alausa, 2006; Ojo \& Fagade, 2002). In Thailand, shoot tips plus young leaves (spl) of LL in fresh or boiled conditions are commonly used as edible vegetables with side dishes of various spicy foods. Only methanol extractions, many parts of the LL extracts have been documented to possess the total phenolic contents (TPCs) and antioxidant activities (Hassan et al., 2014; Benjakul et al., 2013; Maisuthisakul, 2012; Aderogba et al., 2010; Chanwitheesuk et al.). However, the scientific screening of antioxidant capacity of aqueous LL shoot tips plus young leaves (LL-spl) is still limited. Adversely, it is very well known that this plant is toxic to cattle animals

\footnotetext{
" Department of Anatomy, Faculty of Medicine, Khon Kaen University, Khon Kaen, Thailand.

** Center for Research and Development of Herbal Health Products, Faculty of Pharmaceutical Sciences, Khon Kaen University, Khon Kaen, Thailand. *** Department of Pharmaceutical Sciences, Faculty of Pharmacy, Mahasarakham University, Mahasarakham, Thailand.
} 
(Anderson et al., 2001; Hammond, 1995) and used as an antifertility agent in traditional medicine. The domestic or wild animals that consumed the fresh LL leaves in large amounts would have infertility problems and eventually suffer death (Bhatia et al., 2014; Clément et al., 2012; Wayman et al., 1970). Possibly, it was reported that all parts of LL contain the mimosine, a natural toxin proven to have anti cancer activities, cell divisions, cell proliferations and differentiations (Chang et al.; Wang et al., 1995; Krude, 1999; Hughes \& Cook, 1966). Recently, although the LL-spl has been wildly consumed, both antioxidant capacity and toxicity on male reproductive parameters have never been previously documented. Therefore, this study attempted to primarily determine the antioxidant capacity and further examine the acute testicular toxicity of LL-spl extract in male rats.

\section{MATERIAL AND METHOD}

Chemicals and reagents. Folin-Ciocalteu reagent, acetate buffer, 2-diphenyl-picrylhydrazyl (DPPH), 2, 4, 6tripyridyl-s-triazine (TPTZ), and ferric chloride ( $\mathrm{FeCl} 3$ ) were purchased from Sigma-Aldrich Co., Ltd., Thailand. Ascorbic acid, gallic acid, and other chemicals were of analytical grade.

Plant collection and extraction. The fresh shoot tips plus young leafs (spl) of LL were collected from Dang Yai subdistrict, Mueang district, Khon Kaen province, Thailand, in May, 2014 . The collected LL-spl samples were botanically confirmed by Prof. Dr. Pranom Chantaranothai, a plant taxonomist, Department of Biology, Faculty of Science, Khon Kaen University. The voucher specimens of LL-spl were kept in the KKU herbarium (no. Jaturon Burawat 02 [KKU]). For plant collection, after 15 days of trimming the tree branches, the LL-shoot tips plus young leaves (20-22 $\mathrm{cm}$ in length) were harvested. For plant extraction, the LLspl samples were washed with distilled water (DW) and crushed with stone pounder for $30 \mathrm{~min}$. Then, each $1 \mathrm{~kg}$ of crushed sample of LL-spl was extracted with $3 \mathrm{~L}$ of DW and boiled at $95-100{ }^{\circ} \mathrm{C}$ for 10,20 , and $40 \mathrm{~min}$. Based on the boiling times, there were three different extracted fractions (LL-spl 10, 20, and $40 \mathrm{~min}$ respectively). Then, each soluble extract was filtered through nylon cloth and further dried by using the spray dryer (Nitro A/SGladsaxeveg 305-DK-2860, Soeborg, Denmark) (Toyang et al., 2012). As calculated from a formula of yield $(\%)=$ (weight of plant powder extract after extraction) $/(1 \mathrm{~kg}$ of dried plant before extraction) $\times 100 \%$, the extraction powder yields of the LL-spl 10, 20, and 40 min were 3.36\%, 5.35 $\%$, and $6.48 \%$, respectively. Each fraction was further prepared as concentrated extract stock of $2 \mathrm{mg} / \mathrm{mL}$ (dissolved with distilled water) before use.
Determination of TPC. The amount of TPC in all LL-spl different extracts was measured using the Folin-Ciocalteu reagent method as previously described (Iamsaard et al., 2014; Singleton et al., 1999). Briefly, each aqueous LL-spl extract $(0.2 \mathrm{~mL}, 0.2 \mathrm{mg} / \mathrm{mL})$ was added into a test tube containing $1 \mathrm{~mL}$ of the Folin-Ciocalteu reagent $(10 \%, \mathrm{v} / \mathrm{v})$ and incubated for $5 \mathrm{~min}$ before adding $3 \mathrm{~mL}$ of $0.2 \mathrm{~g} / \mathrm{mL}$ sodium carbonate. After mixing the solution thoroughly, the mixed sample was further incubated for $2 \mathrm{~h}$ at room temperature in a dark room with intermittent shaking. Then, the absorbance of each sample was triplicate measured in at $765 \mathrm{~nm}$ using an ultraviolet-visible spectrophotometer (Jasco V530, Japan). To gain a calibration curve, the standard sample used was at five concentrations of diluted gallic acid solutions $(0.040,0.064,0.080,0.120$ and $0.160 \mathrm{mg} / \mathrm{mL}$, respectively). All results of the TPCs were expressed as gallic acid equivalents in milligram per gram of dried sample.

DPPH radical scavenging assay and determination of IC50. The radical scavenging activity of LL-spl extracts was determined by using a DPPH assay as previously described (Iamsaard et al., 2014; Brand-Williams et al., 1995). Briefly, the distilled water-diluted solution of each LL-spl extract $(10,20$, or $40 \mathrm{~min})$ was prepared from a concentrated extract stock into five concentrations $(7,12,19,25,32,38$, and 44 $\mu \mathrm{g} / \mathrm{mL}$, respectively) to complete a concentration plot. Then, each concentration of extract $(2 \mathrm{~mL})$ was mixed with $2 \mathrm{~mL}$ DPPH in methanol $(0.004 \%)$ and incubated for $30 \mathrm{~min}$ at room temperature in the dark room. The absorbance of all samples was recorded at $517 \mathrm{~nm}$ using an ultraviolet-visible spectrophotometer. For the positive standard, the ascorbic acid $(2,6,10,13$, and $16 \mu \mathrm{g} / \mathrm{mL})$ was used to perform the standard plot. All samples were measured in triplicate. The scavenging activity of the extracts or standard was calculated as the percent inhibition of DPPH radical scavenged activity using the formula of the absorbance of control minus the absorbance of sample and divided by the absorbance of control and x100\%. Data were expressed as the IC50 and ascorbic acid equivalent antioxidant capacity (AEAC) based on the formulation of (Chew et al., 2009, 2011).

FRAP assay. Reducing power capacity was determined using an FRAP assay as previously described (Benzie \& Strain, 1996). Briefly, $0.1 \mathrm{~mL}$ of each LL-spl extract $(10,20$, or 40 min) (prepared from a stock solution) at a concentration of $0.2 \mathrm{mg} / \mathrm{mL}$ was mixed with $3 \mathrm{~mL}$ of FREP reagent $(300 \mathrm{mmol} /$ L acetate buffer, $10 \mathrm{mmol} / \mathrm{L} \mathrm{TPTZ,} 20 \mathrm{mmol} / \mathrm{L} \mathrm{FeCl} 3$ [10:1:1, $\mathrm{v} / \mathrm{v} / \mathrm{v}])$. Then, the mixture was incubated for $20 \mathrm{~min}$ in a dark room and recorded for the absorbance at $593 \mathrm{~nm}$ by using an ultraviolet-visible spectrophotometer. To prepare the standard curve, the six concentrations of ascorbic acid $(3.84,7.68$, $15.67,24.00,32.64,40.00$ and $48.00 \mu \mathrm{g} / \mathrm{mL}$ ) were plotted to determine the reducing power. 
Experimental animals. Male Sprague-Dawley rats (200$220 \mathrm{~g}$ ) were purchased from the National Laboratory Animal Center, Salaya, Nakhon Pathom, Thailand, and transferred to the Northeast Laboratory Animal Center, Khon Kaen University, Thailand. To acclimatize animals, rats were housed in plastic cages with stainless steel tops and wood chip bedding under a $12 \mathrm{~h} \mathrm{light/dark} \mathrm{cycle} \mathrm{at} \mathrm{room}$ temperature for a week. For grouping, rats were randomly divided into three groups $(\mathrm{n}=5)$ : Group 1 (control group) orally received $2 \mathrm{ml}$ of distilled water/day by gavage; Group 2 (LL-spl extract 400) orally received $400 \mathrm{mg} / \mathrm{kg}$ body weight per day of LL-spl extract by gavage; Group 3 (LLspl extract 600) orally received $600 \mathrm{mg} / \mathrm{kg}$ body weight per day of LL-spl extract by gavage, respectively. It was noted that the LL-spl extract selected to treat in animals was the best fraction containing highest antioxidant capacity. The administration of LL-spl extract was performed consecutively for 40 days. At the end of experiment, all rats were euthanized by cervical dislocation and sacrificed to collect the blood and male reproductive organs.

Plasma testosterone assay. Following euthanized animals, the blood of rats was immediately collected by cardiac puncture of the left ventricle and the clotting of blood was prevented by heparin. Then, the blood was centrifuged at $13000 \mathrm{rpm}$ at $4{ }^{\circ} \mathrm{C}$ for $7 \mathrm{~min}$ by Microfuge $22 \mathrm{R}$ to separate the plasma serum from blood cells. Subsequently, the serum was sent to the Radiology Unit, Srinagarind Hospital, Faculty of Medicine, KKU, Thailand, for assessment of testosterone levels.

Histopathology. The male reproductive organs (testis, epididymis plus vas deferens, and seminal vesicle) of all groups were subsequently harvested and removed of fats before weighing. Immediately, all organs were fixed with $10 \%$ formalin to maintain tissue. To investigate the testicular histopathology, testes were routinely processed LM technique and stained with hematoxylin and eosin. All testicular sections were observed for tissue damages and captured by a Nikon light ECLIPSE E200 microscope equipped with a DXM1200 digital camera. To quantify tubular atrophy, diameters of seminiferous tubules in each group (100 tubules per animal) were measured in four different axes.

Sperm count assay. For sperm collection, the left caudal epididymis and vas deferens were harvested and dissected out to squeeze mature sperm. Caudal sperm fluid was dipped in to $1 \mathrm{~mL}$ phosphate buffered saline (PBS, $37^{\circ} \mathrm{C}, \mathrm{pH}$ 7.4) to dilute and maintain sperm. The diluted sperm were further centrifuged at $5000 \mathrm{rpm}$ at $25{ }^{\circ} \mathrm{C}$ for 2 min to wash and separate the mature sperm pellet from epididymal fluid. To count the sperm number, the sperm pellets were re-suspen- ded with $1 \mathrm{ml}$ PBS $\left(37{ }^{\circ} \mathrm{C}, \mathrm{pH}\right.$ 7.4) Then, the sperm suspension (1:50 dilution) was loaded on Neubauer counting chamber to count and calculate sperm concentration in triplicate examination (Iamsaard et al., 2013).

Western blot analysis for expression of testicular StAR protein. Testicular tissue was homogenized with RIPA buffer (Cell Signaling Technology, Inc., USA) containing a cocktail of protease inhibitors (Sigma, Inc., USA) to extract and maintain the proteins. Then, the testicular homogenate was centrifuged at $10,000 \mathrm{rpm}$ at $4{ }^{\circ} \mathrm{C}$ for $10 \mathrm{~min}$ to separate testicular protein lysate from its pellet. The total protein concentration of the lysate was further measured using a NanoDrop ND-1000 Spectrophotometer (NanoDrop Technologies, Inc., USA) at absorbance $280 \mathrm{~nm}$. To determine the StAR protein, $80 \mathrm{mg}$ of total testicular proteins of the each sample were loaded and separated on $10 \%$ sodium dodecyl sulfate polyacrylamide gel electrophoresis (SDSPAGE) and electrophoretically transferred to nitrocellulose membrane. The blotted-protein membrane was blocked with $5 \%$ non-fat milk-PBST ( $0.1 \%$ Tween-20 in PBS, pH 7.4) for $1 \mathrm{~h}$, and then incubated with specific anti-StAR $(1: 1000$; Santa Cruz Biotechnology, Inc., USA) or anti-b-actin (1:2000; Santa Cruz Biotechnology, Inc., USA) primary antibody at $4{ }^{\circ} \mathrm{C}$ for overnight. After washing non-specific primary antibody, the antigen-antibody complex membrane was exposed to goat anti-rabbit IgG secondary antibody (conjugated with HRP) for StAR antibody detection whereas it was exposed to goat anti-mouse $\mathrm{IgG}$ secondary antibody (conjugated with HRP) to detect testicular b-actin. Then, the membrane was washed with $0.05 \%$ PBST for about 5 min three times before detection of StAR proteins or b-actin by incubation with the enhanced chemiluminescence (ECL) substrate under gel doct 4 (ImageQuant 400, GH Healthcare, USA).

Statistical analysis. The data was reported as mean \pm standard deviation (SD) and analyzed using one-way analysis of variance (ANOVA) followed by a Student t-test for multiple comparisons using SPSS Statistics 17.0 software. A value of $\mathrm{P}<0.05$ was used considered as significant difference.

\section{RESULTS}

Phenolic contents and antioxidant capacity of LL-spl extracts. The results showed that three different fractions of the LL-spl extracts possessed the total phenolics (Fig. $1 \mathrm{~A})$ as determined from the calibration curves of the gallic acid ( $\mathrm{Y}=0.004 \mathrm{x}-0.074, \mathrm{R}^{2}=0.99$, where $\mathrm{Y}$ is peal area, $\mathrm{X}$ is the concentration $(\mu \mathrm{g} / \mathrm{mL})$ of the marker compound). The 


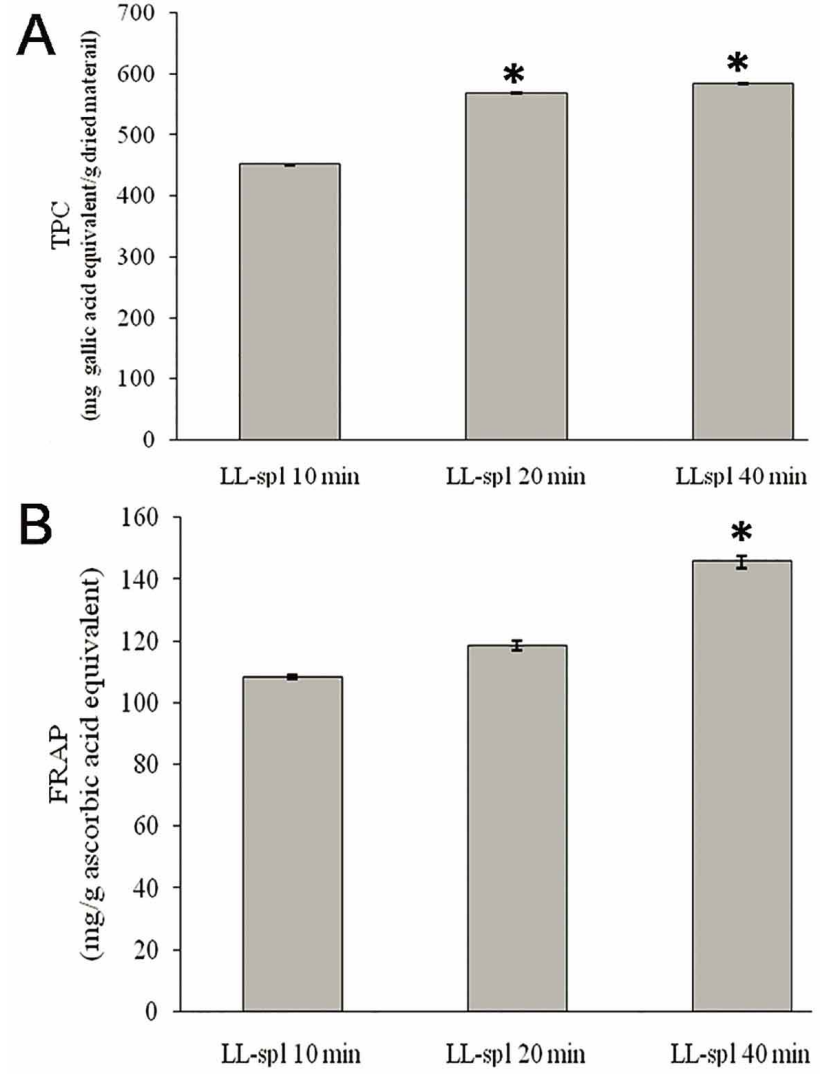

Fig. 1. A) Amount of total phenolic contents (TPCs). B) Ferric reducing antioxidant powers (FRAPs) of the Leucaena leucocephala aqueous shoot tips plus young leaves (LL-spl) extracts in 10, 20, and 40 min. Data are expressed as mean $\pm \mathrm{SD}(\mathrm{n}=3){ }^{*}=\mathrm{P}<0.05$.

fraction of LL-spl (40 min) extract contained the highest TPC (584.58 $\pm 1.84 \mathrm{mg}$ gallic acid equivalent/g dried material), followed by the fractions of LL-spl (20 and $10 \mathrm{~min}$ ) extracts, respectively. Significantly, the extracts of LL-spl 40 and 20 min showed the amount of TPC higher than that of LL-spl 10 min extract (Fig. 1A). For the reducing power capacity assay, the results showed that different extracts of the LL-spl demonstrated concentration-dependent increases in the reducing power as also shown in the calibrated standard ascorbic acid $(\mathrm{Y}=0.0098 \mathrm{x}+0.1333$, $\mathrm{R}^{2}=0.98$ ). Among the LL-spl extracts (Fig. 1B), the result showed that the LL-spl 40 min extract had the significantly highest reduction levels of ferric ion to ferrous sulfate $(145.66 \pm 2.00) \mathrm{mg} / \mathrm{g}$ ascorbic acid equivalent) compared to that of the LL-spl $20 \mathrm{~min}$ and LL-spl 10 min extracts, respectively).

In the 2-diphenyl-picrylhydrazyl (DPPH) scavenging assay, the results showed that different fractions of the LL-spl aqueous extracts possessed a concentrationresponse relationship in the DPPH scavenging activity which was similar to the trend of positive control (ascorbic acid). Compared to IC50 and ascorbic acid equivalent antioxidant capacity (AEAC) among three different fractions, it showed that IC50 of LL-spl 40 min fractions was significantly lowest than that of LL-spl 10 and $20 \mathrm{~min}$ (Table I). In contrast, the value of AEAC of LL-spl 40 min is significantly highest as compared to those of the rest fractions (Table I).

Effect of LL-spl extract on rat body weights. In every 8 days of experiment 40 days, the body weights of control and LL administered rats are shown in Figure 2. All experimental rats normally increased body weights. At the end of experiment, rat body weights in the LL-spl 400 and LL-spl 600 groups $(415.14 \pm 29.19$ and $425.68 \pm 34.72 \mathrm{~g}$ ) were not significantly different as compared with control group (417.46 $\pm 29.19 \mathrm{~g})$.

Effect of LL-spl extract on male reproductive parameters. The LL-spl extracts did not affect on morphology of testis and epididymis plus vas deferens as compared with control group. In contrast, only LL-spl 600 group has smaller size of seminal vesicles as compared with that of LL-spl 400 and control groups (Fig. 3).

After experiment for 40 days, the LL-spl extracts did not reduce the weights of testis and epididymides plus vas deferens as compared with control (Table II). However, the relative weight of seminal vesicles in LL 600 group was significantly different as compared with control group ( $\mathrm{P}<0.05)$. Moreover, the LL-spl extracts significantly reduced spermatozoa concentration and diameter of seminiferous tubules as compared to the control group ( $\mathrm{P}$ $<0.05$ ) (Table II).

Table I. Antioxidant activities of the Leucaena leucocephala aqueous shoot tips plus young leaves (LL-spl) extracts by using the DPPH radical method.

\begin{tabular}{lcc}
\hline LL-spl extract/standard & IC $_{\mathbf{5 0}}(\boldsymbol{\mu g} / \mathbf{m L})$ & AEAC (mg a scorbic/100 g) \\
\hline LL-sp1 $10 \mathrm{~min}$ & $29.90 \pm 0.36$ & $29427.83 \pm 359.93$ \\
LL-spl $20 \mathrm{~min}$ & $27.96 \pm 0.04$ & $31466.09 \pm 53.13$ \\
LL-spl $40 \mathrm{~min}$ & $25.05 \pm 1.17 *$ & $35175.36 \pm 1607.60 *$ \\
\hline
\end{tabular}

$\mathrm{AEAC}=$ Ascorbic acid equivalent antioxidant capacity. Data are expressed as mean $\pm \mathrm{SD}(\mathrm{n}=3) . *=\mathrm{P}<0.05$ vs. LL-spl 10 min or LL-spl 20 min. 
Table II. Effect of LL-spl extract on absolute and relative weights of male reproductive organs, epididymal sperm concentration, and diameter of seminiferous tubules.

\begin{tabular}{llccc}
\hline Parameters & & Control & LL-spl 400 & LL-spl 600 \\
\hline Testes & Absolute weights $(\mathrm{g})$ & $3.81 \pm 0.06$ & $3.68 \pm 0.31$ & $3.97 \pm 0.21$ \\
& Relative weights $(\mathrm{g} / 100 \mathrm{~g})$ & $0.91 \pm 0.06$ & $0.88 \pm 0.08$ & $0.93 \pm 0.07$ \\
Epididymides plus vas deferen & Absolute weights $(\mathrm{g})$ & $0.68 \pm 0.03$ & $0.64 \pm 0.06$ & $0.69 \pm 0.04$ \\
& Relative weights $(\mathrm{g} / 100 \mathrm{~g})$ & $0.16 \pm 0.01$ & $0.15 \pm 0.01$ & $0.16 \pm 0.02$ \\
Seminal vesicles & Absolute weights $(\mathrm{g})$ & $1.50 \pm 0.30$ & $1.61 \pm 0.08$ & $1.23 \pm 0.06$ \\
& Relative weights $(\mathrm{g} / 100 \mathrm{~g})$ & $0.36 \pm 0.08$ & $0.38 \pm 0.04$ & $0.29 \pm 0.02^{*}$ \\
Epididymal spem & Concentration $(106$ cells/mL) & $104.17 \pm 6.27$ & $58.67 \pm 4.93^{*}$ & $67.50 \pm 7.72^{*}$ \\
& Diameter of seminiferous tubules $(\mu \mathrm{m})$ & $306.59 \pm 13.95$ & $269.58 \pm 5.36^{*}$ & $268.24 \pm 9.52^{*}$
\end{tabular}

$*=\mathrm{P}<0.05$ vs. control group. Data are expressed as mean $\pm \mathrm{SD}(\mathrm{n}=5)$.

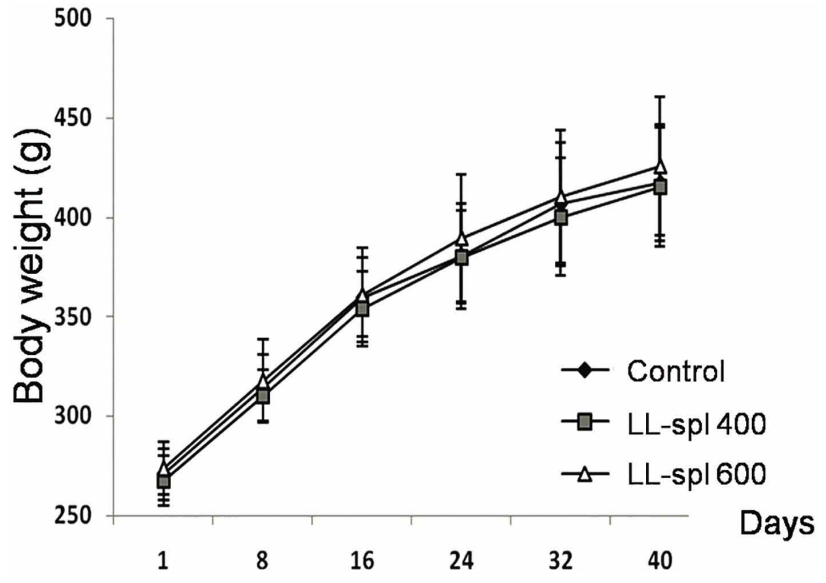

Fig. 2. Showing the increase of rats body weight in control, LL-spl 400 and L-spl 600 groups for 40 days. Each data point represented as mean $\pm \operatorname{SD}(n=5)$.

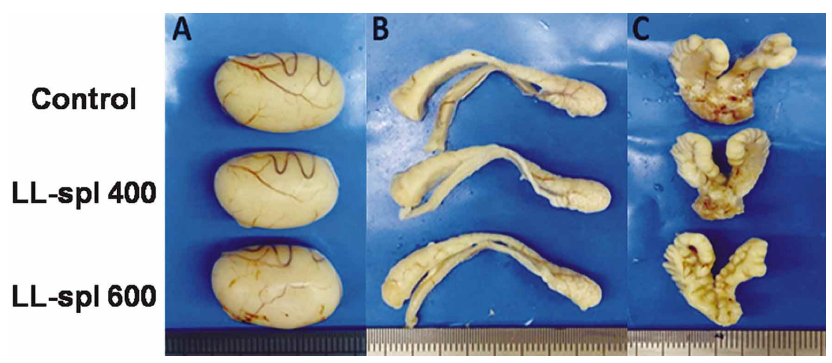

Fig. 3. Photographs showing the gross morphology of testis (A), epididymis plus vas deferens (B), and seminal vesicles (C) of control, LL-spl 400 and LL-spl 600 groups.
Effect of LL-spl extract on serum testosterone level. The serum testosterone ranges of control, LL-spl 400, and LLspl 600 groups are shown in Table III. The results showed that the testosterone levels of both control and LL-spl treated groups were not significantly different.

Effect of LL-spl on histology of testis. The testicular histology of control, LL-spl 400 , and LL-spl 600 groups are shown in Figure 4. The results showed that the control group had normal arrangement of seminiferous epithelium (Spermatogenic cells and Sertoli cells) and interstitial tissues (Fig. 4A). In contrast, it was observed that LL-spl extracts could damage seminiferous tubules around $15-20 \%$ of testicular tissue as compared to control group (Fig. 4B and 4C). In LL-spl 400 group, it was observed that damagedseminiferous tubules were composed of atrophy and germ cells degeneration with increased interstitial spaces and dilated blood vessels. Moreover, the LL-spl 600 group revealed the more severe damage of degenerative seminiferous tubules with dilated blood vessels as compared to control and LL-spl 400 groups (Fig. 4C).

Effect of LL-spl extract on testicular StAR protein expression. In immuno-Western blotting result, the expressions of testicular StAR protein of all groups are shown in Figure 5. After analysis of intensity of testicular StAR protein against the internal control (beta actin), the results showed that all doses of LL-spl extracts did not affect StAR expression as compared to control (Fig. 5).

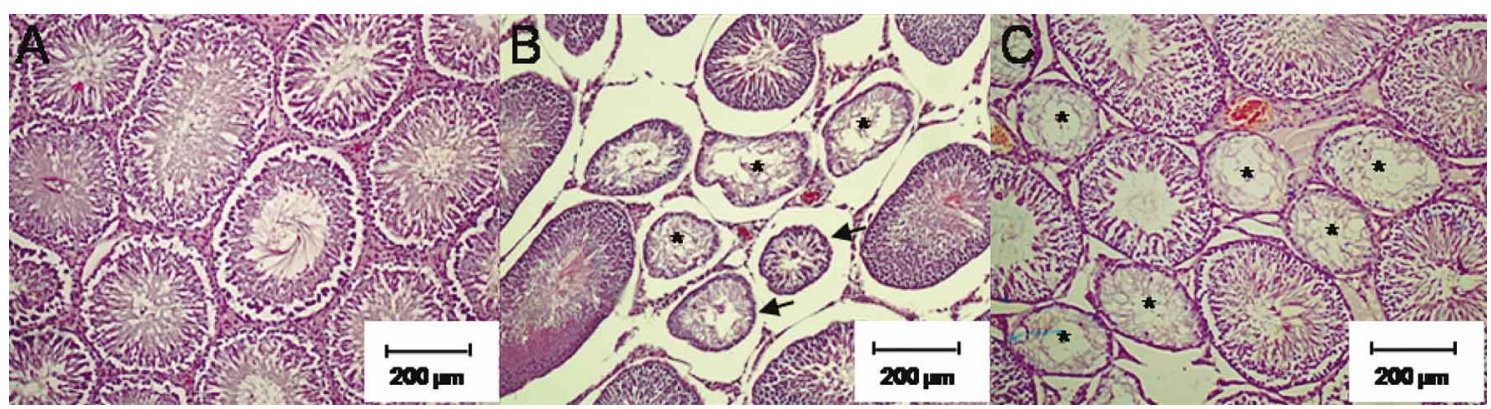

Fig. 4. Histomicrographs showing the testicular tissues of control (A), LL-spl 400 (B), and LL-spl 600 (C) groups, respectively. Atrophic seminiferous tubules (asterisks); Degenerative seminiferous tubules (arrows). 


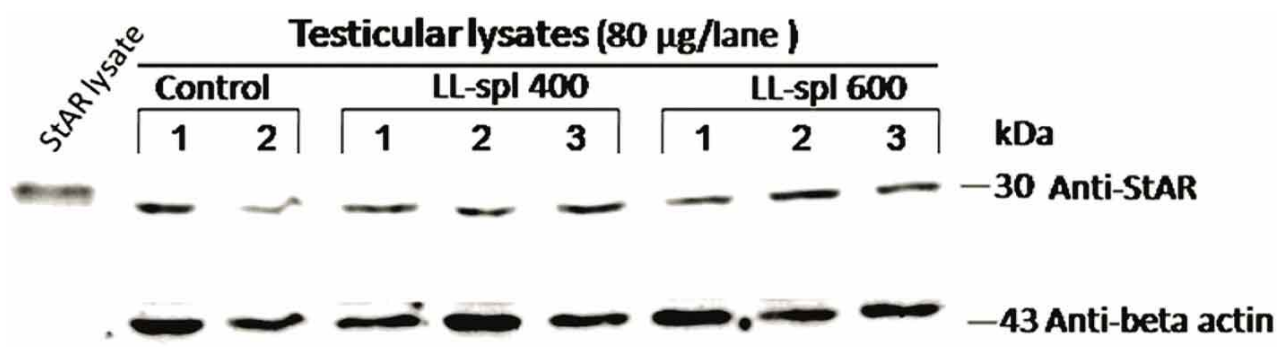

Fig. 5. Immuno-Western blot showing the expression levels of testicular StAR protein in rat testicular lysate of control (n=2), LL-spl 400, and LL-spl 600 groups $(n=3)$.

Table III. Effect of Leucaena leucocephala extract on testosterone levels.

\begin{tabular}{lcc}
\hline Groups $(\boldsymbol{n}=\mathbf{5})$ & Range $(\mathbf{n g} / \mathbf{m L})$ & Mean $(\mathbf{n g} / \mathbf{m L})$ \\
\hline Control & $0.28-5.51$ & 2.04 \\
LL-spl 400 and 600 & $0.16-6.09$ & 2.23 \\
\hline
\end{tabular}

\section{DISCUSSION}

In Thailand especially in rural areas, Leucaena leucocephala shoot tips plus young leaves (LL-spl) are widely consumed as a sweet vegetable on spicy side dishes. For aqueous extract, resent study has already reported that LL-spl extract contained total phenolic and antioxidant capacities for the first time. In particularly methanol/acetone extract, previous study has demonstrated that only LL-shoot tip has highest antioxidant index and total phenolic as compared to those of plants in Leguminosae family (Chanwitheesuk et al.). In addition, young and mature leaves of LL have been documented to have various chemical constituents like crude proteins, beta-carotene, quercetins, and total flavonoids (Hassan et al.; Benjakul et al.; Maisuthisakul; Aderogba et al.). In scientific improvements, bark, leaves, and seeds of L. leucocephala have been documented to have many pharmaco-therapeutic activities (Syamsudin et al.; Gamal-Eldeen et al.; Ademola et al.; Chang et al.; Villaseñor et al.). Depending on recent results, it is obvious that LL-spl 40 min showed highest amount of total phenolic and antioxidant capacities (Fig. 1 and Table I). This implies that more boiling of LL-spl is important for extraction to gain more such antioxidant capacities. As high antioxidant capacities of LL-spl extract have been shown in recent study (Fig. 1 and Table I), there were no changes in the weights of body, testis, and epididymis as compared to those of control (Table II). In corroboration with no significant differences of serum testosterone between control and LL-spl treated groups, the expression of testicular StAR protein (a cholesterol carrier protein in testosterone synthesis) revealed by immune western blot was not different among groups (Fig. 5). In contrast, it was reported that LLseed extract composed of many mineral constituents and some toxic substances such as tannin, mimosine and saponin
(Alabi \& Alausa; Ojo \& Fagade). Traditionally, LL plant has been used as abortifacient, contraception, and relieving diarrhea. Unfortunately, the LL-spl extract was not quantified to determine accurate levels of mimosine which was known to be a toxin agent that can inhibit cellular divisions, proliferations and differentiations (Chang et al.; Wang et $a l . ;$ Krude; Hughes \& Cook). Therefore, it can be explained why the crude extract of L. leucocephala has been demonstrated to have many anti-cancer activities (Syamsudin et al.; Gamal-Eldeen et al.; Ademola et al.; Chang et al.; Villaseñor et al.). For support the actions of $L$. leucocephala in abortifacient and contraceptive properties, this study significantly demonstrated its acute toxicity on some male reproductive parameters (i.e., seminal vesicle morphology, sperm concentration, and seminiferous tubule diameters) and testicular tissue (Table II, Figs. 3 and 4). We believe that these adverse effects might be caused from mimosine and other toxic molecules in LL-spl extract. However, the levels of mimosine and other infertile substances of LL- shoot tips plus young leaves extracts need to be further investigated since this part of plant nowadays, is mostly used for consumption.

\section{ACKNOWLEDGEMENTS}

This study was financially supported by a Postgraduate Study Support Grant and Invitation Grant, Faculty of Medicine, Khon Kean University, Thailand to Mr. Jaturon Burawat, a Ph.D. candidate of anatomy program, under supervision of Dr. Sitthichai Iamsaard and Nongnut Uabandit (Grant Number IN59140). 
BURAWAT, J.; UABANDIT, N.; SRIPANIDKULCHAI, B.; NUALKAEW, S. \& IAMSAARD, S. Capacidad antioxidante y toxicidad testicular aguda de brotes acuosos con extracto de hojas nuevas de Leucaena leucocephala. Int. J. Morphol., 34(2):514-521, 2016.

RESUMEN: El objetivo fue determinar la capacidad antioxidante del extracto de brotes acuosos con hojas nuevas de Leucaena leucocephala (LL-spl) en tres fracciones diferentes (LL-SPL 10, 20 y 40 min), además de examinar su toxicidad aguda sobre los parámetros reproductivos masculinos. Se determinó la cantidad de los fenoles totales en el extracto de LL-spl utilizando un método reactivo de Folin-Ciocalteu. La capacidad antioxidante se analizó por medio de 1-difenil-2-picrilhidracilo y/o métodos de reducción férrica de la capacidad antioxidante. La fracción de extracto LL-spl con mayor capacidad antioxidante fue utilizada en el tratamiento de los animales. Ratas macho fueron divididas en tres grupos $(\mathrm{n}=5)$ : el control y los grupos tratados con LL-spl 400 y $600 \mathrm{mg} / \mathrm{kg}$ peso corporal por 40 días consecutivos. El resultado mostró que la fracción LL-spl 40 min poseía la mayor capacidad antioxidante. Además, los grupos 400 y 600 LL-spl no mostraron diferencias según el peso corporal, testículos y epidídimo, niveles de testosterona y la expresión de proteínas testiculares. El extracto de LL-spl redujo de manera significativa el peso de la vesícula seminal, la concentración de espermatozoides y los diámetros de los túbulos seminíferos en comparación con el control. Por otra parte, el extracto de LL-spl tuvo un efecto adverso sobre la histología testicular por la inducción de atrofia y degeneración de los túbulos seminíferos, incluyendo a vasos sanguíneos dilatados en el tejido intersticial. Si bien el extracto LL-spl posee una capacidad antioxidante, ésta podría ser tóxica en el consumo a corto plazo para algunos órganos reproductores masculinos y especialmente dañino para los tejidos testiculares.

PALABRAS CLAVE: Leucaena leucocephala; Brotes con hojas nuevas; Capacidad antioxidante; Toxicidad testicular aguda.

\section{REFERENCES}

Ademola, I. O.; Akanbi, A. I. \& Idowu, S. O. Comparative nematocidal activity of chromatographic fractions of Leucaena leucocephala seed against gastrointestinal sheep nematodes. Pharm. Biol., 43(7):599-604, 2005.

Aderogba, M. A.; McGaw, L. J.; Bezabih, B. T. \& Abegaz, B. M. Antioxidant activity and cytotoxicity study of Leucaena leucocephala (Lam.) de wit leaf extract constituents. Niger. J. Nat. Prod. Med., 13(1):65-8, 2010.

Alabi, D. A. \& Alausa, A. A. Evaluation of the mineral nutrients and organic food contents of the seeds of Lablab purpureus, Leucaena leucocephala and Mucuna utilis for domestic consumption and industrial utilization. World J. Agric. Sci., 2(1):115-8, 2006.

Anderson, R. C.; Anderson, T. J.; Nisbet, D. J.; Kibbe, A. S.; Elrod, D. \& Wilkinson, G. Drought associated poisoning of cattle in South Texas by the high quality forage legume Leucaena leucocephala. Vet. Hum. Toxicol., 43(2):95-6, 2001.

Benjakul, S.; Kittiphattanabawon, P.; Shahidi, F. \& Maqsood, S. Antioxidant activity and inhibitory effects of lead (Leucaena leucocephala) seed extracts against lipid oxidation in model systems. Food Sci. Technol. Int., 19(4):365-76, 2013.

Benzie, I. F. \& Strain, J. J. The ferric reducing ability of plasma (FRAP) as a measure of "antioxidant power": the FRAP assay. Anal. Biochem., 239(1):70-6, 1996.

Bhatia, H.; Manhas, R. K.; Kumar, K. \& Magotra, R. Traditional knowledge on poisonous plants of Udhampur district of Jammu and Kashmir, India. J. Ethnopharmacol., 152(1):207-16, 2014.
Brand-Williams, W.; Cuvelier, M. E. \& Berset, C. Use of a free radical method to evaluate antioxidant activity. L. W. T. - Food Sci. Technol., 28(1):25-30, 1995.

Chang, H. C.; Lee, T. H.; Chuang, L. Y.; Yen, M. H. \& Hung, W. C. Inhibitory effect of mimosine on proliferation of human lung cancer cells is mediated by multiple mechanisms. Cancer Lett., 145(1-2):1-8, 1999.

Chanwitheesuk, A.; Teerawutgulrag, A. \& Rakariyatham, N. Screening of antioxidant activity and antioxidant compounds of some edible plants of Thailand. Food Chem., 92(3):491-7, 2005.

Chew, Y. L.; Chan, E. W.; Tan, P. L.; Lim, Y. Y.; Stanslas, J. \& Goh, J. K. Assessment of phytochemical content, polyphenolic composition, antioxidant and antibacterial activities of Leguminosae medicinal plants in Peninsular Malaysia. B. M. C. Complement. Altern. Med., 11:12, 2011.

Chew, Y. L.; Goh, J. K. \& Lim, Y. Y. Assessment of in vitro antioxidant capacity and polyphenolic composition of selected medicinal herbs from Leguminosae family in Peninsular Malaysia. Food Chem., 116(1):13-8, 2009.

Clément, C.; Witschi, U. \& Kreuzer, M. The potential influence of plant-based feed supplements on sperm quantity and quality in livestock: a review. Anim. Reprod. Sci., 132(1-2):1-10, 2012.

Gamal-Eldeen, A. M.; Amer, H.; Helmy, W. A.; Ragab, H. M. \& Talaat, R. M. Antiproliferative and cancer-chemopreventive properties of sulfated glycosylated extract derived from Leucaena leucocephal. Indian J. Pharm. Sci., 69(6):805-11, 2007. 
Gutteridge, R. C. \& Shelton, H. M. (Eds.). Forage Tree Legumes in Tropical Agriculture. Queensland, Tropical Grassland Society of Australia, Inc., 1998.

Hammond, A. C. Leucaena toxicosis and its control in ruminants. J. Anim. Sci., 73(5):1487-92, 1995.

Hassan, R. A.; Tawfik, W. A. \& Abou-Setta, L. M. The flavonoid constitunts of Leucaena leucocephala. Growing in Egypt, and their biological activity. Afr. J. Tradit. Complement. Altern. Med., 11(1):67-72, 2014.

Hughes, T. A. \& Cook, P. R. Mimosine arrests the cell cycle after cells enter S-phase. Exp. Cell. Res., 222(2):275-80, 1996.

Iamsaard, S.; Arun, S.; Burawat, J.; Sukhorum, W.; Wattanathorn, J.; Nualkaew, S. \& Sripanidkulchai, B. Phenolic contents and antioxidant capacities of Thai-Makham Pom (Phyllanthus emblica L.) aqueous extracts. J. Zhejiang Univ. Sci. B, 15(4):4058, 2014.

Iamsaard, S.; Prabsattroo, T.; Sukhorum, W.; Muchimapura, S.; Srisaard, P.; Uabundit, N.; Thukhammee, W. \& Wattanathorn, J. Anethum graveolens Linn. (dill) extract enhances the mounting frequency and level of testicular tyrosine protein phosphorylation in rats. J. Zhejiang Univ. Sci. B, 14(3):247-52, 2013.

Krude, T. Mimosine arrests proliferating human cells before onset of DNA replication in a dose-dependent manner. Exp. Cell. Res., 247(1):148-59, 1999.

Maisuthisakul, P. Phenolic Constituents and Antioxidant Propertied of some Thai Plants. In: Rao, V. (Ed.). Phytochemicals - A Global Perspective of Their Role in Nutrition and Health. Rijeka, InTech, 2012.

Ojo, O. A. \& Fagade, O. E. Persistence of Rhizobium inoculants originating from Leucaena leucocephala fallowed plots in Southwest Nigeria. Afr. J. Biotechnol., 1(1):23-7, 2002.

Orwa, C.; Mutua, A.; Kindt, R.; Jamnadass, R. \& Anthony, S. Agroforestree Database: a tree reference and selection guide version 4.0. Nairobi, World Agroforestry Centre, 2009.

Singleton, V. L.; Orthofer, R. \& Lamuela-Raventós, R. M. Analysis of Total Phenols and other Oxidation Substrates and Antioxidants by Means of Folin-Ciocalteu Reagent. In: Packer, L. (Ed.). Methods in Enzymology. San Diego, Academic Press Inc., 299:152-178, 1999.

Syamsudin; Sumarny, R. \& Simanjuntak, P. Antidiabetic activity of active fractions of Leucaena leucocephala (lmk) dewit seeds in experiment model. Eur. J. Sci. Res., 43(3):384-91, 2010.

Toyang, N. J.; Ateh, E. N.; Keiser, J.; Vargas, M.; Bach, H.; Tane, P.; Sondengam, L. B.; Davis, H.; Bryant, J. \& Verpoorte, R. Toxicity, antimicrobial and anthelmintic activities of Vernonia guineensis Benth. (Asteraceae) crude extracts. J. Ethnopharmacol., 144(3):700-4, 2012.
Villaseñor, I. M.; Gajo, R. M. T. \& Gonda, R. C. Bioactivity studies on the alkaloid extracts from seeds of Leucaena leucocephala. Phytother. Res., 11(8):615-7, 1997.

Wang, Y.; Zhao, J.; Clapper, J.; Martin, L. D.; Du, C.; DeVore, E. R.; Harkins, K.; Dobbs, D. L. \& Benbow, R. M. Mimosine differentially inhibits DNA replication and cell cycle progression in somatic cells compared to embryonic cells of Xenopus laevis. Exp. Cell. Res., 217(1):84-91, 1995.

Wayman, O.; Iwanaga, I. I. \& Hugh, W. I. Fetal resorption in swine caused by Leucaena leucocephala (Lam.) de Wit. in the diet. J. Anim. Sci., 30(4):583-8, 1970.

Correspondence to:

Sitthichai lamsaard

Department of Anatomy

Faculty of Medicine

Khon Kaen University

Khon Kaen, 40002

THAILAND

Email: sittia@kku.ac.th

Received: 04-08-2015

Accepted: 05-04-2016 